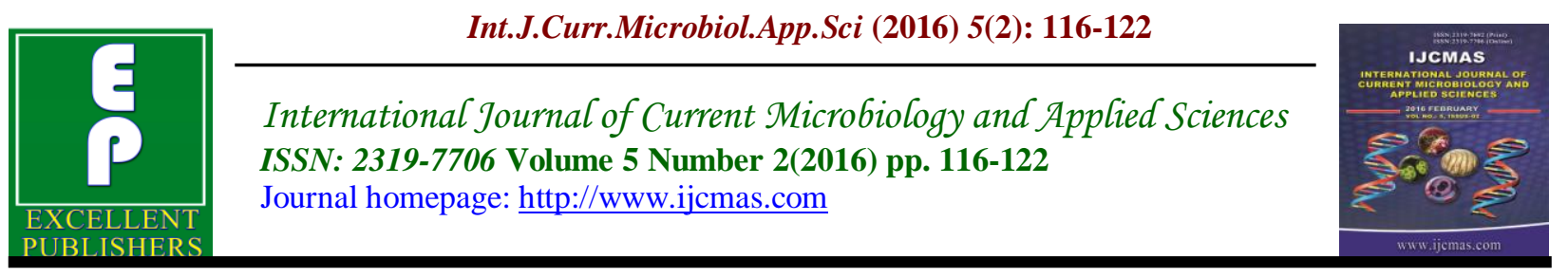

Original Research Article

doi: http://dx.doi.org/10.20546/ijcmas.2016.502.013

\title{
Preliminary Phytochemical Screening of Different Solvent Extracts of Selected Indian Spices
}

\author{
V. Jyothiprabha* and P.Venkatachalam \\ PG and Research Department of Microbiology, Sengunthar Arts and Science College, \\ Thiruchengode-637205, Namakkal, India \\ *Corresponding author
}

Keywords

Phytochemical analysis, alkaloids, Saffron, Nutmeg,

Article Info

Accepted:

10 January 2015

Available Online:

10, February 2016

\section{A B S T R A C T}

Spices has been added to foods since ancient times, not only as flavoring agent, but also as food preservatives and folk medicines. The present study focuses on thephytochemical analysis of five well known Indian spices namely clove, pepper, nutmeg, cinnamon and saffron. Phytochemical compositions of spices were carried out for the methanol, ethanol, acetone, chloroform and distilled water extracts. Qualitative phytochemical analysis of these spices extracts confirm the presence of various phytochemicals like alkaloids, carbohydrates, phenol, glycosides, terpanoids, flavonoids, saponins, proteins, steroids and tannins.

\section{Introduction}

India is one of the largest producer, consumer and exporter of spices. India grows over fifty spices out of the eighty six grown worldwide. They also play an important role in our national economy. On the world market, about twenty major spices are traded. Spices are considered as rich source of bio- active antimicrobial compounds. Spices are also used for stabilizes in several food items from deterioration. Particularly in Ayurveda, spices contributed a major amount for the treatment of key disorders of the body.
Homeopathic medicine has been using spices as one of the chief ingredients in most of their preparations.

Spices are used as substances that increase the taste and variation of food. (Ceylon, 1997 andBulduk, 2004).According to world health organization (WHO), more than $80 \%$ of theworld's population relies on traditional medicines for their primary health care needs. (Himalet al., 2008). The medicinal value of spices, which include leaves (coriander,mint), buds (clove), bulbs (garlic, 
onion),fruits (red chili, black pepper), stem(cinnamon), rhizomes (ginger) and other plant parts, have been defined asplant substances from indigenous or exotic origin, aromatic or with strong taste, used to enhance the taste of foods.

Phytochemicals are bio- active chemicals of plant origin. They are regarded as secondary metabolites because the plant that manufactures them may have little need for them. They are naturally synthesized in all parts of the plant body; bark, leaves stem, root, flower, fruits, seeds, etc. i.e. any part of the plant body may contain active components (Tiwariet al., 2011).

Saffron (Crocussativus) is an important spice belongs to Family lridaceae, known for its aroma, colour and medicinal properties and is regarded as the most costly spice in the world (Mohammad et al., 2011).Syzygiumaromaticum commonly known as cloves are the aromatic flower buds of a tree in the family Myrtaceae. Cloves are used in Indian Ayurvedic medicine, Chinese medicine and Western herbalism. Piper nigrum commonly known as black pepper is a flowering vine in the family Piperaceae, cultivated for its fruit, which is usually dried and used as a spice. Cinnamomumverum commonly known as cinnamon is a spice obtained from the bark of a tree in the family Lauraceae. Myristica fragrans commonly known as nutmeg is a seed of a tree in the family Myristicaceae.

\section{Materials and Methods}

\section{Collection of Spices}

The four spices (clove, cinnamon, nutmeg and pepper) were collected from Spices Research Centre Calicut and Saffron from Kashmir. The spices were cleaned and washed in sterile distilled water and air dried at room temperature. The dried spices were powdered using blender.

\section{Preparation of Spices Extracts}

10 gram of powdered spices were weighed and mixed with $100 \mathrm{ml}$ of five different solvents (methanol, ethanol, acetone, chloroform and distilled water) in conical flasks and kept in rotatory shaker at $150 \mathrm{rpm}$ for 24 hours. After 24 hours it was filtered with Whatman No.1 filter paper. The filtrates were evaporated in a hot air oven at $40^{\circ} \mathrm{C}$ until dry. One gram dried extracts were resuspended in $10 \mathrm{ml}$ of Dimethyl Sulphoxide (DMSO) individually. The extracts were stored in sample bottles at $4^{\circ} \mathrm{C}$ prior to use.

\section{Phytochemical Screening of Spices}

Phytochemical screening was carried out on methanol, ethanol, acetone, chloroform and distilled water extracts of spices for its chemical composition.(Kokateet al 2003andChitravadivuet al., 2009). The following tests were performed to detect various phytochemical constituents present in them.

\section{Screening for Alkaloids (Mayer's Test)}

To $2 \mathrm{ml}$ of the extract was boiled with dilute hydrochloric acid and the mixture was filtered and to the filtrate a few drops of Mayer's reagent was added. A cream or white colour precipitate produced immediately indicates the presence of alkaloids.

\section{Screening for Carbohydrate test}

To $1 \mathrm{ml}$ of extract, $1 \mathrm{ml}$ of Benedict's reagent was added. The mixture is heated on a boiling water bath for 2 minutes solution appeared green showing the presence of reducing sugar. 


\section{Screening of Phenol}

To $1 \mathrm{ml}$ of the extract $3 \mathrm{ml} 10 \%$ lead acetate solution was added. A bulky white precipitate indicates the presence of phenolic compounds.

\section{Screening Forglycosides (Keller Kilianin Test)}

$5 \mathrm{ml}$ of each extract was added with $2 \mathrm{ml}$ of glacial acetic acid which was followed by the addition of few drops of ferric chloride solution and $1 \mathrm{ml}$ of concentrated Sulphuric acid. Formation of brown ring at interface confirms the presence of glycosides.

\section{Screening for Terpanoids (Salkowski Test)}

$5 \mathrm{ml}$ of extract was taken in a test tube and $2 \mathrm{ml}$ of chloroform was added to it followed by the addition of $3 \mathrm{ml}$ of concentrated sulphuric acid. Formation of reddish brown layer at the junction of two solutions confirms the presence of terpanoids.

\section{Screening for Flavonoids (Alkaline Reagent Test)}

$2 \mathrm{ml}$ of extracts was treated with few drops of $20 \%$ sodium hydroxide solution formation of intense yellow colour, which becomes colourless on addition of dilute hydrochloric acid, indicates the presence of flavonoids.

\section{Screening for Saponins (Foam Test)}

$2 \mathrm{ml}$ of extract was taken in a test tube and $6 \mathrm{ml}$ of distilled water was added to it. The mixture was shaken vigorously and observed for the formation of persistent foam that confirms the presence of saponins.

\section{Screening for Proteins}

$5 \mathrm{ml}$ of extract was mixed with $10 \% \mathrm{NaOH}$ solution and added few drops of copper sulphate to it. The formation of reddish violet colour indicates the presence of proteins.

\section{Screening for Steroids}

$1 \mathrm{ml}$ of extract was dissolved in $10 \mathrm{ml}$ of chloroform and equal volume of concentrated sulphuric acid was added by the sides of the test tube. The upper layer turns red and sulphuric acid layer showed yellow with green fluorescence. This indicates the presence of steroids.

\section{Screening for Tannins}

$2 \mathrm{ml}$ of extract was added to few drops of $1 \%$ lead acetate. A yellowish precipitate indicated the presence of tannins.

\section{Results and Discussion}

In the present studies phytochemical screening of five spices clove, cinnamon, pepper, nutmeg and saffron were done. The phytochemical analysis of five spices is presented in tables2 to 6.The result reveals that some of the phytochemicals analysed were present in the extracts of all the spices.

On the ten phytochemicals screened, glycosides and terpanoids were present commonly in all the studied spices. From clove extracts, (Table-2) glycosides, phenols and terpanoids were present in methanol, acetone and chloroform extracts. Ethanol extracts had glycosides, phenols, terpanoids and steroids. Distilled water extracts had glycosides and phenols. From pepper extracts,(Table-3) alkaloids, glycosides, phenols, terpanoids and carbohydrates were present in all pepper extracts. In ethanol pepper extract steroids were present. Acetone pepper extract steroids and tannins were also present. From cinnamon extracts, (Table-4) glycosides, saponins, phenols and 
terpanoids were present in all the cinnamon extracts. Carbohydrates were present only in acetone cinnamon extract. From nutmeg extracts, (Table-5) alkaloids, glycosides, saponins, phenols, flavonoids, terpanoids and proteins were present in all the nutmeg extracts. Carbohydrates were present in ethanol, chloroform and distilled water extracts. From saffron extracts, (Table-6) glycosides, saponins, steroids, terpanoids and tannins were present in all the saffron extracts.

Table.1 Botanical Information of Selected Spices

\begin{tabular}{|c|c|c|c|c|}
\hline No & Botanical name & $\begin{array}{c}\text { Common } \\
\text { name }\end{array}$ & Family & Part used \\
\hline 1 & Cinnamomumverum & Cinnamon & Lauraceae & Bark \\
\hline 2 & Piper nigrum & Pepper & Piperaceae & Seed \\
\hline 3 & Syzygium aromaticum & Clove & Myrtaceae & Flower bud \\
\hline 4 & Myristica fragrans & Nutmeg & Myristicaceae & Seed \\
\hline 5 & Crocus sativus & Saffron & Iridaceae & Flower \\
\hline
\end{tabular}

Table.2 Phytochemical Analysis of Clove Extracts

\begin{tabular}{|l|l|l|l|l|l|l|}
\hline S.No & Phytochemical Test & Methanol & Ethanol & Acetone & Chloroform & D.W \\
\hline 1 & Alkaloids & - & - & - & - & - \\
\hline 2 & Glycosides & + & + & + & + & + \\
\hline 3 & Saponnin & - & - & - & - & - \\
\hline 4 & Phenol & + & + & + & + & + \\
\hline 5 & Steroids & - & + & - & - & - \\
\hline 6 & Flavanoids & - & - & - & - & - \\
\hline 7 & Terpanoids & + & + & + & + & - \\
\hline 8 & Protein & - & - & - & - & - \\
\hline 9 & Tannins & - & - & - & - & - \\
\hline 10 & Carbohydrates & - & - & - & - & - \\
\hline
\end{tabular}

Table.3 Phytochemical Analysis of Pepper Extracts

\begin{tabular}{|c|c|c|c|c|c|c|}
\hline S.No & Phytochemical Test & Methanol & Ethanol & Acetone & Chloroform & D.W \\
\hline 1 & Alkaloids & + & + & + & + & + \\
\hline 2 & Glycosides & + & + & + & + & + \\
\hline 3 & Saponnin & _- & - & - & _ & _- \\
\hline 4 & Phenol & + & + & + & + & + \\
\hline 5 & Steroids & - & + & + & $=$ & \\
\hline 6 & Flavanoids & $\ldots$ & _ & _ & _ & _ \\
\hline 7 & Terpanoids & + & + & + & + & + \\
\hline 8 & Protein & - & - & $\ldots$ & - & - \\
\hline 9 & Tannins & - & - & + & - & - \\
\hline 10 & Carbohydrates & + & + & + & + & + \\
\hline
\end{tabular}


Table.4 Phytochemical Analysis of Cinnamon Extracts

\begin{tabular}{|c|c|c|c|c|c|c|}
\hline S.No & Phytochemical Test & Methanol & Ethanol & Acetone & Chloroform & D.W \\
\hline 1 & Alkaloids & _ & _ & _ & - & _- \\
\hline 2 & Glycosides & + & + & + & + & + \\
\hline 3 & Saponnin & + & + & + & + & + \\
\hline 4 & Phenol & + & + & + & + & + \\
\hline 5 & Steroids & _- & - & _- & - & _- \\
\hline 6 & Flavanoids & _ & - & _- & - & _ \\
\hline 7 & Terpanoids & + & + & + & + & + \\
\hline 8 & Protein & _- & _- & - & - & _ \\
\hline 9 & Tannins & - & - & - & - & _- \\
\hline 10 & Carbohydrates & _ & _ & _ & - & _ \\
\hline
\end{tabular}

Table.5 Phytochemical Analysis of Nutmeg Extracts

\begin{tabular}{|c|c|c|c|c|c|c|}
\hline S.No & Phytochemical Test & Methanol & Ethanol & Acetone & Chloroform & D.W \\
\hline 1 & Alkaloids & + & + & + & + & + \\
\hline 2 & Glycosides & + & + & + & + & + \\
\hline 3 & Saponnin & + & + & + & + & + \\
\hline 4 & Phenol & + & + & + & + & + \\
\hline 5 & Steroids & _- & _- & _- & _- & _- \\
\hline 6 & Flavanoids & + & + & + & + & + \\
\hline 7 & Terpanoids & + & + & + & + & + \\
\hline 8 & Protein & + & + & + & + & + \\
\hline 9 & Tannins & _- & _- & _- & _ & _- \\
\hline 10 & Carbohydrates & - & + & _- & + & + \\
\hline
\end{tabular}

Table.6 Phytochemical Analysis of Saffron Extracts

\begin{tabular}{|l|l|l|l|l|l|l|}
\hline S.No & Phytochemical Test & Methanol & Ethanol & Acetone & Chloroform & D.W \\
\hline 1 & Alkaloids & - & - & - & - & - \\
\hline 2 & Glycosides & + & + & + & + & + \\
\hline 3 & Saponnin & + & + & + & + & + \\
\hline 4 & Phenol & - & - & - & - & - \\
\hline 5 & Steroids & + & + & + & + & + \\
\hline 6 & Flavanoids & + & + & + & + & + \\
\hline 7 & Terpanoids & + & + & + & + & + \\
\hline 8 & Protein & - & - & - & - & - \\
\hline 9 & Tannins & + & + & + & + & + \\
\hline 10 & Carbohydrates & - & - & - & - & - \\
\hline
\end{tabular}


Spices have been added to foods since ancient times as flavoring agent, also as food preservatives and folk medicines. Basically when spices are used for medicinal purpose, their value is depend on the phytochemicals they possess (Okwu 2001). The spices, herbs, plant extract and their phytoconstituents have been reported for anti-inflammatory, antidiarrheal, antimicrobial, antioxidant and insecticidal activities (Chouhan and Singh, 2011).In the present study, the extract of pepper and nutmeg showed the presence of alkaloids. Alkaloid has important biological property like cytotoxicity and are used in allophatic systems (Trease and Evans, 2005). Steroids are present in ethanol clove, ethanol pepper, acetone pepper and saffron extracts. Steroids and Sterols are great importance in pharmacy as they possess compounds like sex hormones and can be used for drug production.(Okwu, 2001).In the present investigation glycosides are present in all the five spices. The glycosides are useful in lowering blood pressure. (Nyarko et al., 1990). They are also used in the treatment of congestive heart failure and cardiac arrhythmia. Terpanoids are also present in all the studied spices. Terpanoids are used in the treatment of cough, asthma and hay fever. Saponins are present in cinnamon, nutmeg and saffron extracts. Traditionally saponins have been extensively used as detergents and pesticides, in addition to their industrial applications as foaming and surface active agents and also beneficial health effects (Shi et al., 2004). Saponins protect against hypercholesterolemia and antibiotics properties (Amin et al., 2013). Tannins are present only in saffron extracts. The growth of many fungi, yeast, bacteria and viruses was inhibited by tannins (Chung et al., 1998). Phenols and tannins acts as antioxidants (Han et al., 2005).

In conclusion, the selected five spices in this study consist of many useful phytocompounds having important biological properties. The result of this study would lead to find out some compounds which are very useful for the manufacturing of new drugs. The previous phytochemical analysis and present studies show nearly the similar results due to the presence of phytochemical constituents.

\section{References}

Amin Mir M., Sawhney, S.S. and Jassal, M.M.S.2013. Qualitative and quanditative analysis of phytochemicals of Taraxacum officinale. Wudpecker J. Phar. and Pharmaco. 2 (1): 001-005.

Bulduk S, 2004 Food Technology. $2^{\text {nd }}$ edition Daley Publishing Ankara, Turkey.

C.K.Kokate. 1993. Practical pharmacognosy. Vallabhprakashan, Delhi India.107-111.

Ceylan A. 1997. Medical Plants-ll Volatile Oil Plants. Ege University, Faculty of Agriculture, Department of Field Crops, lzmir, Turkey.

Chitravadivu C., Manian.S and Kalaichelvi K. 2009.Qualitative Analysis of Selected Medicinal Plants. Tamilnadu, India Middle-East journal of Scientific Research. 4(3):144-146.

Chouhan H.S., Singh S.K.A. 2001. Review of plants of genus Leucas. $J$ of pharmacognosy and phytotherapy. 3(3): 13-26.

Chung, K.T., T.Y. Wong, C.L. Wei, Y.W. Huang and Y. Lin 1998.Tannins and human health.A review, Criti. Rev. Food. Sci. Nutri. 6:421-446.

Han X., Shen T. and Lou H. 2005.Dietary polyphenols and their biological significance. Int. J. Mol. Sci. 8(9): 
950-988.

Mohammad Anwar khan, SabeenaNaseer, ShaheenaNagoo, F.A.Nehvi, 2011.Behaviour of Saffron (C.sativus) corms for daughter corm production .J.Phytol. 3(7):47-49.

Nyarko A. A., Addy M. E.1990. Effects of aqueous extract of Adeniacis sampeloides on blood pressure and serum analyze of hypersensitive patients. Phytotherapy Res. 4(1): 2528.

Okwu D. E. Evaluation of the chemical composition of indigenous Spices and flavoring Agents. Global J. Pure Appl.Sci.,7(3),455-459,2001
Okwu D. E.2001. Evaluation of the chemical composition of medicinal plants belonging to Euphorbiaceae. Pak. Vet. J. 14: 160-162.

P. Tiwari, B. Kumar, M. Kaur, G. Kaur, H. Kaur.2011. Int. pharm. Sciencia. 1: 98-106.

Shi, J.K., Arunasalam, D., Yeung, Y., Kakuda, G., Mittal and Y. Jiang. 2004. Saponins from edible legumes. Chemistry, Processing and health benefits. J. Med. Food. 7: 67-78.

Trease G. E., and Evans M. C.2005. Pharmacognosy. Elsevier,14 th ed. 53: 431-512.

\section{How to cite this article:}

Jyothiprabha, V., and Venkatachalam, P. 2016. Preliminary Phytochemical Screening of Different Solvent Extracts of Selected Indian Spices. Int.J.Curr.Microbiol.App.Sci. 5(2):116122. doi: http://dx.doi.org/10.20546/ijcmas.2016.502.013 